\title{
Purification and Partial Characterization of an Amylase from Lysobacter brunescens
}

\author{
By R. G. VON TIGERSTROM* AND S. STELMASCHUK \\ Department of Microbiology, University of Alberta, Edmonton, Alberta T6G 2E9, Canada
}

(Received 27 March 1987; revised 29 June 1987)

Four species of the genus Lysobacter, especially L. brunescens and L. gummosus, produced amylase when grown in liquid medium containing starch. The amylase was purified nearly $1200-$ fold with a $36 \%$ yield from the culture supernatant of $L$. brunescens by ammonium sulphate precipitation, CM-52 cellulose chromatography and gel filtration. An $M_{\mathrm{r}}$ of 47000-49000 was estimated for the enzyme from results of SDS-PAGE and glycerol gradient centrifugation, respectively. Metal ions such as $\mathrm{Mg}^{2+}, \mathrm{Ca}^{2+}, \mathrm{Mn}^{2+}$ or $\mathrm{Zn}^{2+}$ are not required for activity. The amylase is active from pH 5.0 to 7.5, degrades starch endohydrolytically and has a $K_{\mathrm{m}}$ of $2.08 \mathrm{mg}$ starch $\mathrm{ml}^{-1}$. Amylopectin, amylose and glycogen were also hydrolysed. Dextran, maltose, maltotriose, maltotetraose and 4-nitrophenyl $\alpha$-D-glucoside were hydrolysed very slowly, or not at all. Other enzymes capable of degrading starch, maltose or malto-oligosaccharides were not detected in the culture supernatant of $L$. brunescens.

\section{INTRODUCTION}

The genus Lysobacter, order Cytophagales (Reichenbach, 1981) contains four recognized species, L. antibioticus, L. brunescens, L. enzymogenes and $L$. gummosus, as well as a number of strains or subspecies (Christensen \& Cook, 1978). These organisms produce several extracellular enzymes (Jackson \& Matsueda, 1970; Whitaker, 1970; Christensen \& Cook, 1978; von Tigerstrom, 1980, 1981, 1983, 1984) as well as the antibiotic myxin and gummy polysaccharides (Christensen \& Cook, 1978). All species we have investigated so far produce proteinases and peptides appear to be their preferred carbon and energy source. Carbohydrates such as monosaccharides are used slowly, particularly in the case of $L$. enzymogenes (unpublished). However, a number of polysaccharides are degraded by these organisms and L. brunescens appears to be particularly active in this regard (Christensen \& Cook, 1978). Since most of the hydrolytic activities were determined by plate assays (Christensen \& Cook, 1978), none of these polysaccharide-degrading enzymes have been investigated in detail. We selected $L$. brunescens for the study of an amylase. The production of this enzyme, its purification and some of its characteristics are reported in this paper.

\section{METHODS}

Chemicals. Soluble starch (S-516) was a product of Fisher. All other substrates, phosphorylase $b$ and the glucose oxidase-peroxidase kit for the determination of glucose were purchased from Sigma. The protein standards were from Pierce. Catalase from bovine liver was obtained from Calbiochem and Escherichia coli $\mathrm{C}_{4} \mathrm{~F}_{1}$ phosphatase was prepared in this laboratory (von. Tigerstrom, 1983). Carboxymethylcellulose CM-52 (CM-52 cellulose) and Sephadex G-75 superfine were the products of Whatman and Pharmacia, respectively, and the TLC plastic sheets with silica gel 60 were from Merck.

Growth of the organisms. The Lysobacter species .were obtained from Dr F. D. Cook, University of Alberta. Freeze-dried cultures were prepared for long-term maintenance. Short-term maintenance at $4{ }^{\circ} \mathrm{C}$ was done after growth at $20-22{ }^{\circ} \mathrm{C}$ on $0.4 \%$ tryptone, $1 \%(\mathrm{w} / \mathrm{v})$ skim milk, $1.75 \%(\mathrm{w} / \mathrm{v})$ agar. For the production of amylase, $L$. brunescens ATCC 29486 was grown for $48 \mathrm{~h}$ in $0.8 \%$ tryptone, $0.2 \%$ yeast extract, $0.3 \%$ starch, $2 \mathrm{mM}-\mathrm{MgCl}_{2}$ at 20 
$22^{\circ} \mathrm{C}$ with shaking at 200 r.p.m. The initial and final $\mathrm{OD}_{600}$ values were 0.03 and 5.3 , respectively. The cells were removed by centrifugation at $16300 \mathrm{~g}$ for $15 \mathrm{~min}$ and the culture supernatants were retained. The other organisms were treated in the same way.

Enzyme assays. Amylase activity was routinely determined at $37{ }^{\circ} \mathrm{C}$ by incubating $250 \mu 11 \%(\mathrm{w} / \mathrm{v})$ starch, $50 \mathrm{mM}$-Tris/HCl, $\mathrm{pH} 7.5$, with up to $100 \mu \mathrm{l}$ enzyme solution diluted with $50 \mathrm{~mm}$-Tris/ $\mathrm{HCl}, \mathrm{pH} 7.5$. The reactions were terminated by the addition of $500 \mu \mathrm{l}$ dinitrosalicylic acid reagent (Miller, 1959). Colour was allowed to develop for $5 \mathrm{~min}$ at $95-97^{\circ} \mathrm{C}$ and the $A_{550}$ was determined after the addition of $2.5 \mathrm{ml} \mathrm{H}_{2} \mathrm{O}$. The $A_{550}$ values were converted to $\mu \mathrm{mol}$ reducing sugar using glucose as the standard $\left(A_{550} 2 \cdot 2=1 \mu \mathrm{mol}\right)$. Other polysaccharides were used as substrates where indicated. Rates of hydrolysis of maltose and other oligosaccharides were determined by detecting the amounts of glucose released. The hydrolysis of 4-nitrophenylglucosides was followed by monitoring the increase in $A_{400}$. Amylase activities are expressed in terms of units (U), where $1 \mathrm{U}$ produces $1 \mu$ mol glucose equivalents $\mathrm{min}^{-1}$. Catalase (Chance \& Maehly, 1955), alkaline phosphatase (von Tigerstrom, 1984) and proteinase (von Tigerstrom, 1980) were assayed according to previously published procedures.

Glycerol gradient centrifugation. Step gradients consisting of $1.9 \mathrm{ml}$ each of $30,25,20,15,10$ and $5 \%(\mathrm{v} / \mathrm{v})$ glycerol in $25 \mathrm{mM}$-Tris/ $\mathrm{HCl}, \mathrm{pH} \mathrm{7.5}$, were allowed to equilibrate at $4{ }^{\circ} \mathrm{C}$ for $20 \mathrm{~h}$. Samples of $0.3 \mathrm{ml}$ containing $6 \mathrm{U}$ amylase, $0.6 \mathrm{mg}$ ovalbumin $\left(M_{\mathrm{r}} 45000\right), 0.3 \mathrm{mg}$ cytochrome $c\left(M_{\mathrm{r}} 12500\right), 45 \mu \mathrm{g}$ catalase $\left(M_{\mathrm{r}} 230000\right)$ and 0.2 units $E$. coli alkaline phosphatase $\left(M_{\mathrm{r}} 84000\right)$ were applied to the gradients. The preparations were centrifuged at $4{ }^{\circ} \mathrm{C}$ in a SW40 Ti rotor at $202000 \mathrm{~g}_{\mathrm{av}}$ for $24 \mathrm{~h}$. Fractions (approximately $0.5 \mathrm{ml}$ ) were collected from the bottom of the tubes and analysed for enzyme activity, $A_{280}$ and $A_{530}$. The experiment was done twice in duplicate with minor variations and the results were in good agreement.

SDS-PAGE. This was done as described earlier (Maizel, 1971; von Tigerstrom \& Stelmaschuk, 1985) using phosphorylase $b\left(M_{\mathrm{r}} 97000\right)$, BSA $\left(M_{\mathrm{r}} 67000\right)$, ovalbumin $\left(M_{\mathrm{r}} 45000\right)$, chymotrypsinogen $\left(M_{\mathrm{r}} 25000\right)$ and cytochrome $c\left(M_{\mathrm{r}} 12500\right)$ as the standard proteins. Starch, $0.05 \%$, was included in the gels for determining amylase

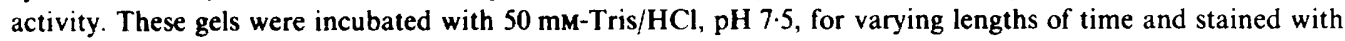
$0 \cdot 1 \% \mathrm{I}_{2}, 0 \cdot 2 \% \mathrm{KI}$ solution.

Analysis of products of the amylase reaction. At $37^{\circ} \mathrm{C}, 400 \mu \mathrm{l} 1 \%$ starch in $50 \mathrm{~mm}-\mathrm{Tris} / \mathrm{HCl}, \mathrm{pH} 7 \cdot 5$, were reacted with $375 \mu \mathrm{l}$ amylase $(17 \mathrm{U})$ in $50 \mathrm{mM}-\mathrm{Tris} / \mathrm{HCl}, 0.5 \mathrm{mg} \mathrm{BSA} \mathrm{ml}^{-1}, \mathrm{pH} 7 \cdot 5$. At timed intervals, $100 \mu \mathrm{l}$ samples of the reaction mixture were withdrawn, heated rapidly at $97^{\circ} \mathrm{C}$ for $3 \mathrm{~min}$ to inactivate the amylase and cooled for storage. Samples $(3 \mu \mathrm{l})$ were spotted on precoated silica gel sheets together with about $15 \mathrm{nmol}$ each of standard glucose, maltose and malto-oligosaccharides. The silica gel sheets were developed using acetic acid/chloroform/ acetone/ $\mathrm{H}_{2} \mathrm{O}(7: 3: 3: 1$, by vol.), a modification of the solvent used by Thirunavukkarasu \& Priest (1984). The detection of the products has been described (Kelly et al., 1986).

Analytical methods. Protein concentrations were determined by the Lowry method and by measuring the $A_{280}$ (Warburg \& Christian, 1941). Cytochrome $c$ was detected by $A_{280}$ and $A_{530}$ measurements. The assay for $\mathrm{NH}_{4}^{+}$has been described (von Tigerstrom, 1980).

Purification. All procedures were done at $0-4{ }^{\circ} \mathrm{C}$. The method described below is representative of three similar purifications done at the same scale with slight modifications.

1. Ammonium sulphate precipitation. Ammonium sulphate ( $1683 \mathrm{~g}$ ) was dissolved in 31 culture supernatant to obtain $80 \%$ saturation. The $\mathrm{pH}$ was adjusted to 5.0 with glacial acetic acid and the mixture was stirred slowly for $60 \mathrm{~min}$. The precipitate was obtained by centrifugation at $25900 \mathrm{~g}$ for $30 \mathrm{~min}$ and dissolved in $50 \mathrm{~mm}-\mathrm{Tris} / \mathrm{HCl}$, $\mathrm{pH} \mathrm{7.3,} \mathrm{to} \mathrm{a} \mathrm{volume} \mathrm{of} 108 \mathrm{ml}$. This was dialysed against $3 \times 2150 \mathrm{~mm}-\mathrm{Tris} / \mathrm{HCl}, \mathrm{pH} \mathrm{7.3}$, and $137 \mathrm{ml} \mathrm{were}$ recovered.

2. CM-52 cellulose chromatography. The dialysed ammonium sulphate preparation was applied to a CM-52 cellulose column $(4 \times 22 \mathrm{~cm})$ equilibrated with starting buffer $(10 \mathrm{mM}-\mathrm{Tris} / \mathrm{HCl}, 25 \mathrm{mM}-\mathrm{KCl}, \mathrm{pH} 7 \cdot 3)$. The column was eluted with $350 \mathrm{ml}$ starting buffer and then with a linear gradient consisting of $600 \mathrm{ml}$ starting buffer and $600 \mathrm{ml} 10 \mathrm{~mm}-\mathrm{Tris} / \mathrm{HCl}, 0.6 \mathrm{M}-\mathrm{KCl}, \mathrm{pH} 7 \cdot 3$. Fractions of about $18 \mathrm{ml}$ were collected and assayed for amylase activity, $A_{280}$ and salt concentration. The amylase in fractions $43-50(151 \mathrm{ml})$ was pooled and concentrated to $5 \mathrm{ml}$ by ultrafiltration using a Diaflo PM10 membrane.

3. Gel filtration. The concentrated amylase preparation was applied to a Sephadex G-75 superfine column $(2.5 \times 20.4 \mathrm{~cm})$, equilibrated and eluted with $25 \mathrm{~mm}-\mathrm{Tris} / \mathrm{HCl}, 100 \mathrm{mM}-\mathrm{KCl}, \mathrm{pH} 7.5$. Fractions of $2.6 \mathrm{ml}$ were collected and assayed for amylase activity and $A_{280}$. Fractions $35-39$ were pooled and stored at $-20^{\circ} \mathrm{C}$. The Sephadex column was calibrated with blue dextran, ovalbumin, cytochrome $c$ and ammonium sulphate.

The purification is summarized in Table 1 and the chromatographic steps are shown in Fig. 1.

\section{RESULTS AND DISCUSSION}

All four species of the genus Lysobacter were grown initially as described in Methods to determine the amounts of amylase produced. L. enzymogenes ATCC 29487 and L. antibioticus ATCC 29479 had the lowest activities, 0.013 U per OD $_{600}$ unit, whereas L. gummosus 

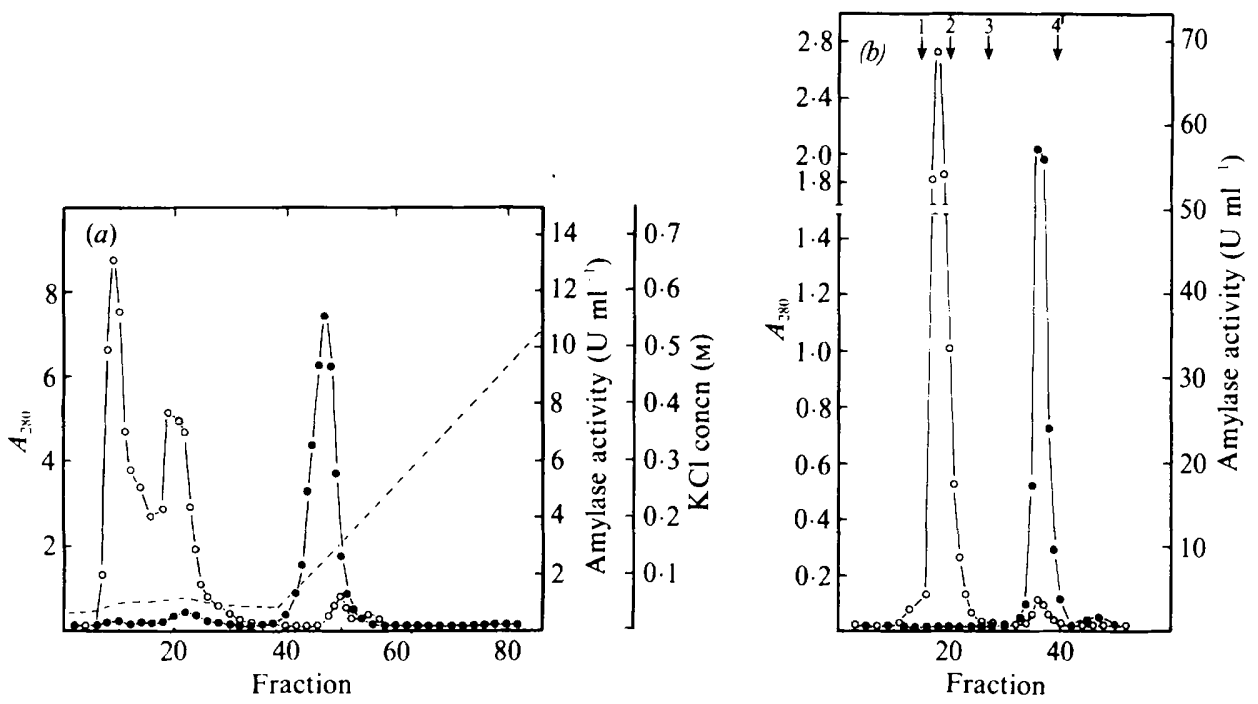

Fig. 1. Purification of $L$. brunescens amylase by CM-52 cellulose chromatography $(a)$ and Sephadex G75 gel filtration $(b)$ as described in Methods (steps 2 and 3). Amylase activities $(O), A_{280}(O)$ and $\mathrm{KCl}$ concentrations (-- ) were determined. Numbers $1-4$ in part $b$ indicate the points of elution of blue dextran, ovalbumin, cytochrome $c$ and $\mathrm{NH}_{4}^{+}$, respectively.

\section{Table 1. Purification of amylase from L. brunescens}

The enzyme was purified as described in Methods. Corrections have been made for the removal of samples for activity and protein determination.

\begin{tabular}{lccccc}
\multicolumn{1}{c}{ Purification step } & $\begin{array}{c}\text { Total } \\
\text { protein } \\
(\mathrm{mg})\end{array}$ & $\begin{array}{c}\text { Total } \\
\text { amylase } \\
(\mathrm{U})\end{array}$ & $\begin{array}{c}\text { Specific activity } \\
{\left[\mathrm{U}(\mathrm{mg} \text {. protein })^{-1}\right]}\end{array}$ & $\begin{array}{c}\text { Purification } \\
\text { (fold) }\end{array}$ & $\begin{array}{c}\text { Proteinase } \\
\text { activity } \\
\left(\Delta A_{370} \text { min }^{-1}\right)\end{array}$ \\
Culture supernatant & 3990 & 1246 & 0.31 & - & 7200 \\
$\left(\mathrm{NH}_{4}\right)_{2} \mathrm{SO}_{4}$ precipitation & 568 & 969 & $1 \cdot 7$ & $5 \cdot 5$ & 6588 \\
$\mathrm{CM}^{-52}$ cellulose & 63 & 987 & $15 \cdot 7$ & 51 & 930 \\
Sephadex G-75 superfine & 1.2 & 445 & 371 & 1197 & $\leq 1 \cdot 2$
\end{tabular}

ATCC 29489 and L. brunescens ATCC 29486 produced 0.073 and $0.066 \mathrm{U}$ per $\mathrm{OD}_{600}$ unit, respectively. Although $L$. gummosus had the highest activity, it was not chosen for further studies since it produces a very viscous culture supernatant which complicates the purification of extracellular enzymes. Further studies were carried out with $L$. brunescens. It grew with a generation time of about $4 \mathrm{~h}$ and produced the amylase after the exponential growth phase.

Amylase purification. L. brunescens produces several proteinases and other extracellular enzymes in addition to the amylase. A primary concern during the purification was the removal of the proteolytic activity from the amylase. The purification is summarized in Table 1 and the proteinase activities are also given for each step. Ammonium sulphate precipitation was used primarily as a means of concentrating the enzyme. Other methods such as ultrafiltration and ion exchange adsorption were not practical at this stage. This step also resulted in a five- to six-fold purification although most of the proteinase activity was retained. During dialysis, a precipitate, probably polysaccharide, was formed at low ionic strength. We found that about $50 \%$ of the enzyme was associated with this particulate material. The dialysed preparation was applied to the CM-52 cellulose column as a fine suspension, i.e. without centrifugation, to avoid loss of the adsorbed amylase activity. The ion exchange chromatography on CM-52 cellulose (Fig. 1a) resulted in a ninefold purification of the amylase and in a significant reduction of the proteinase 


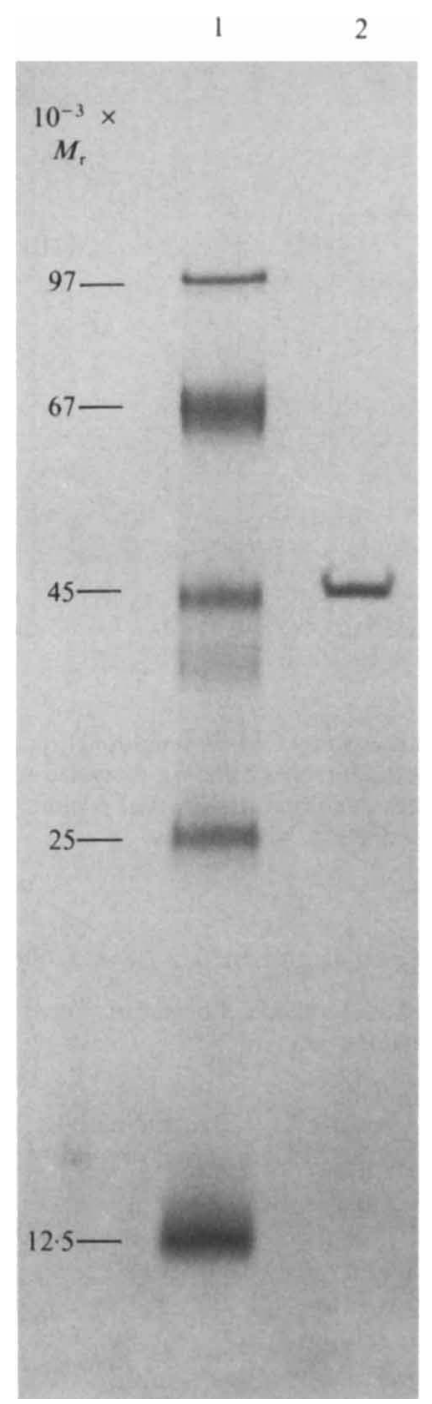

Fig. 2. SDS-PAGE of $L$. brunescens amylase. Lane 1 contains $M_{\mathrm{r}}$ standards (phosphorylase $b$, BSA, ovalbumin, chymotrypsinogen and cytochrome $c)$ and lane 2 contains $75 \mu \mathrm{l}(5.6 \mu \mathrm{g})$ amylase from purification step 3, dialysed against $10 \mathrm{~mm}-\mathrm{Tris} / \mathrm{HCl}, \mathrm{pH} 8 \cdot 0$.

activity. The amylase was recovered in good yield. The fact that the amylase activity appears slightly lower in the previous step is due, in part, to inhibition of the enzyme by ammonium ions.

The last step, gel filtration on Sephadex G-75 superfine (Fig. 1b), resulted in an unusually good purification. Fortuitously, the amylase was retarded during the gel filtration and separated from other high- $M_{\mathrm{r}}$ substances. At this stage the amylase was nearly homogeneous and essentially free of protease activity. In the final preparation the amylase was purified 1237 -fold and obtained in a $36 \%$ yield.

Retardation during Sephadex gel filtration has also been observed with an Acinetobacter amylase (Onishi \& Hidaka, 1978). This might suggest that the Sephadex is a substrate analogue to which the enzyme binds reversibly. However, we found that the affinity of the amylase was even more pronounced with Sephacryl S-200. The amylase was eluted from Sephacryl S-200 very slowly, if at all, with buffer containing $100 \mathrm{mM}-\mathrm{KCl}$; with $0.5 \mathrm{M}-\mathrm{KCl}$, the enzyme was eluted 
with poor recovery in a broad peak after two to three column volumes. Detergents and higher salt concentrations, such as $2 \mathrm{M}-\mathrm{KCl}$, had no significant effect on the elution pattern. Attempts to use this adsorption phenomenon for a one-step purification have been unsuccessful so far.

$M_{r}$ and purity. Since the results in Fig. $1(b)$ indicated an $M_{\mathrm{r}}$ much lower than that of cytochrome $c$, gel filtration could not be used to estimate the $M_{\mathrm{r}}$ of the amylase. Therefore, we used glycerol gradient centrifugation with catalase, $E$. coli alkaline phosphatase, ovalbumin and cytochrome $c$ as the reference proteins. The amylase was eluted just before ovalbumin and an $M_{\mathrm{r}}$ of about 49000 was estimated. The results of the SDS-PAGE (Fig. 2) were in agreement with this. The purified amylase had one major component with an $M_{\mathrm{r}}$ of about 47000 . Although we were unable to renature the protein to obtain amylase activity in polyacrylamide gels, we propose that the major protein band is due to the purified enzyme. The unusual behaviour of the enzyme on gel filtration and the absence of other protein bands support this assumption. Therefore, the amylase is likely to be composed of one polypeptide.

Treatment of the amylase with SDS at room temperature resulted in several activity bands upon PAGE. This probably was due to variable binding of the SDS to the enzyme, resulting in conformational isomers.

Optimum activity and stability of the amylase. The enzyme had a broad $\mathrm{pH}$ optimum with nearly maximum activity from $\mathrm{pH} 5.0$ to $7 \cdot 5$. However, it was less stable at lower $\mathrm{pH}$ values and, therefore, the enzyme was assayed and stored at $\mathrm{pH} 7 \cdot 5$.

Incubation of the enzyme in $50 \mathrm{~mm}$-Tris/ $\mathrm{HCl}, 2 \mathrm{~mm}$-EDTA, $\mathrm{pH} 7.5$, at $20^{\circ} \mathrm{C}$ for $10 \mathrm{~min}$ reduced its activity by $20-23 \%$. An assay of this EDTA-treated amylase in a solution with excess $2 \mathrm{mM}-\mathrm{MgCl}_{2}, \mathrm{CaCl}_{2}$ or $1 \mathrm{mM}-\mathrm{MnCl}_{2}$ or $\mathrm{ZnCl}_{2}$ resulted in some reactivation of the enzyme. This was most pronounced with $\mathrm{CaCl}_{2}$ where nearly all of the lost activity was regained. Addition of $\mathrm{CaCl}_{2}$ to amylase not treated with EDTA resulted in little or no increase in activity.

We have not detected any unusual instability of the enzyme. For instance, at $75 \mu \mathrm{g} \mathrm{ml}^{-1}$ in $25 \mathrm{~mm}-\mathrm{Tris} / \mathrm{HCl}, 100 \mathrm{~mm}-\mathrm{KCl}, \mathrm{pH} 7 \cdot 5$, or in $50 \mathrm{~mm}-\mathrm{Tris} / \mathrm{HCl}, \mathrm{pH} 7 \cdot 5$, the enzyme was stable for at least $9 \mathrm{~d}$ at 0 or $-20^{\circ} \mathrm{C}$. The diluted amylase $\left(3.5 \mu \mathrm{g} \mathrm{ml}^{-1}\right)$ was much less stable under these conditions but inactivation of the enzyme could be prevented by the addition of $100 \mu \mathrm{g}$ BSA ml-1.

Incubation at $55{ }^{\circ} \mathrm{C}$ for $20 \mathrm{~min}$ inactivated $67 \%$ of the enzyme. This loss was reduced to $20 \%$ in the presence of $2 \mathrm{mM}^{-} \mathrm{CaCl}_{2}$ or $500 \mu \mathrm{g} \mathrm{BSA} \mathrm{ml}{ }^{-1}$. The addition of both $\mathrm{CaCl}_{2}$ and $\mathrm{BSA}$ prevented inactivation at $55^{\circ} \mathrm{C}$.

Substrate specificity, $K_{m}$ and mode of action. Amylase activity was routinely determined with solubilized starch. With amylopectin the activity was $95 \%$ and with amylose or glycogen the activities were $65 \%$ of that obtained with starch. Dextran, maltose, 4-nitrophenyl $\alpha$ - or $\beta$-Dglucosides were not hydrolysed. The $K_{\mathrm{m}}$ for starch was determined with varying starch concentrations from 7.4 to $0.71 \mathrm{mg} \mathrm{ml}^{-1}$ and found to be $2.08 \mathrm{mg} \mathrm{ml}^{-1}$ after plotting the inverse of the reaction rates against the inverse of the substrate concentrations.

It was estimated that a purified amylase preparation with $36 \mathrm{U}$ amylase $\mathrm{ml}^{-1}$ produced only $80,0.8,2 \cdot 3$ and $29 \mathrm{nmol}$ glucose equivalents $\min ^{-1}$ (ml enzyme) ${ }^{-1}$ from starch, maltose, maltotriose and maltotetraose, respectively. Thus, the enzyme cleaves the $\alpha-1,4$-glycosidic bonds of larger oligo- and polysaccharides. This mode of action was confirmed by the experiment shown in Fig. 3. Starch was hydrolysed with purified amylase and very little glucose was produced throughout the degradation. After $5 \mathrm{~min}$ four major products were present, maltose, maltotriose, maltotetraose and maltopentaose. Whereas the two larger oligosaccharides were degraded during continued incubation, maltose and maltotriose were degraded very slowly, if at all. Thus, these two products and presumably limit dextrins (not analysed) appear to be the end products of the amylase reaction. Similar results were obtained with crude amylase preparations indicating that the organism is incapable of degrading starch completely. Also, $\alpha$-glucosidase activity in the culture supernatant was very low $\left(1 \times 10^{-4} \mathrm{U} \mathrm{ml}^{-1}\right)$. Thus, maltose and maltotriose probably are hydrolysed only intracellularly. Therefore, the amylase of $L$. brunescens is a typical $\alpha$-amylase (Fogarty, 1983; Priest, 1984).

L. brunescens produces about as much amylase activity per cell as an amylase positive Bacillus subtilis (unpublished). However, the Lysobacter amylase probably will not become an enzyme of 


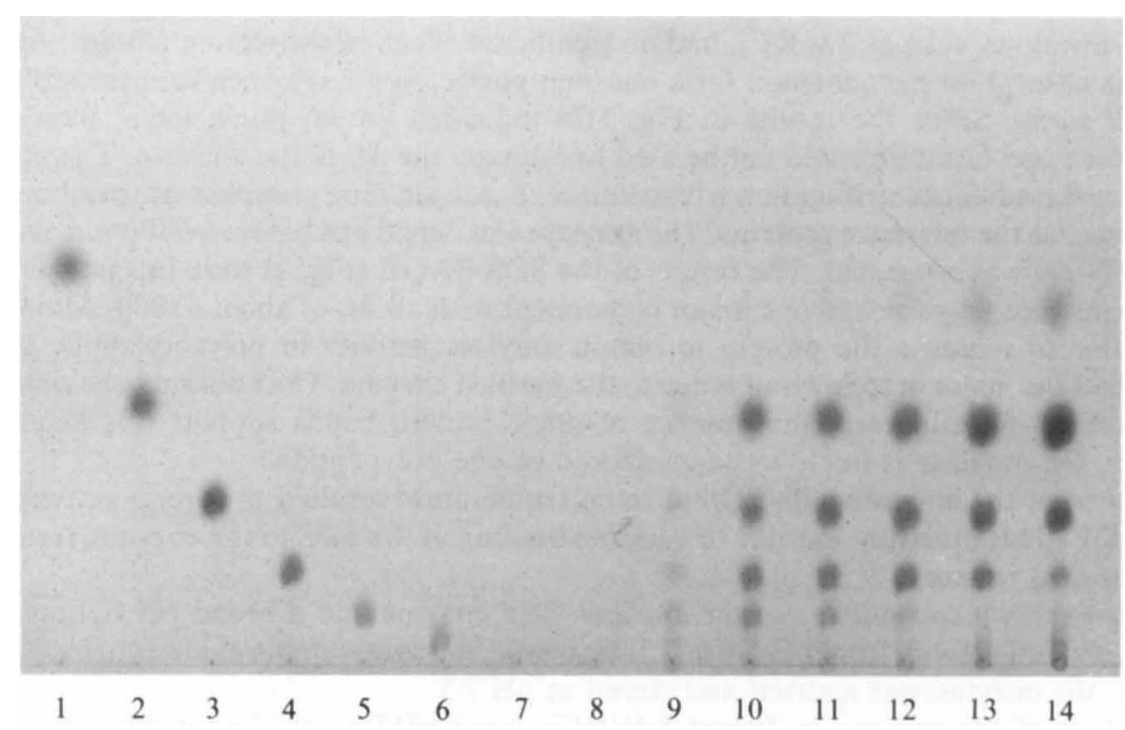

Fig. 3. Analysis of starch degradation by $L$. brunescens amylase as described in Methods. Positions $1-6$ contained glucose, maltose, maltotriose, maltotetraose, maltopentaose and maltohexaose, respectively. Position 7 was a control without starch and positions 8-14 were samples removed after $0,1,5,10,25$, 180 and 630 min degradation, respectively.

commercial importance. Compared to established producers of amylase such as fungal and Bacillus species, the yield of about $1 \mathrm{mg} \mathrm{l}^{-1}$ is low and the enzyme lacks the desired heat stability and other properties important in industry. Thus, the enzyme described here is primarily of interest in the study of the physiology of Lysobacter species and related bacteria. Secondly, it is one of only a very few amylases reported from Gram-negative bacteria (Fogarty, 1983; Priest, 1984). Furthermore, the amylase is of interest since it is one of a number of extracellular enzymes that these Gram-negative bacteria excrete into the environment and the organism may be useful in elucidating the control of exoenzyme synthesis and the excretory process in Gram-negative bacteria.

We thank Barbara Yip for technical assistance. This work was supported by the Natural Sciences and Engineering Research Council of Canada.

\section{REFERENCES}

Chance, B. \& Maehly, A. C. (1955). Assay of catalases and peroxidases. Methods in Enzymology 2, 764-775.

Christensen, P. \& COOK, F. D. (1978). Lysobacter, a new genus of non-fruiting gliding bacteria with a high base ratio. International Journal of Systematic Bacteriology 28, 367-393.

FOGARTY, W. M. (1983). Microbial amylases. In Microbial Enzymes and Biotechnology, pp. 1-92. Edited by W. M. Fogarty. Barking: Applied Science Publishers.

JaCkson, R. L. \& Matsueda, G. R. (1970). Myxobacter AL-1 protease. Methods in Enzymology 19, 591-599.

Kelly, C. T., Giblin, M. \& Fogarty, W. M. (1986). Resolution, purification, and characterization of two extracellular glucohydrolases, $\alpha$-glucosidase and maltase, of Bacillus licheniformis. Canadian Journal of Microbiology 32, 342-347.
Maizel, J. V., JR (1971). Polyacrylamide gel electrophoresis of viral proteins. Methods in Virology 5, 179-246.

Miller, G. L. (1959). Use of dinitrosalicylic acid reagent for determination of reducing sugars. Analytical Biochemistry 31, 416-428.

Onishi, H. \& Hidaka, O. (1978). Purification and properties of amylase produced by a moderately halophilic Acinetobacter sp. Canadian Journal of Microbiology 24, 1017-1023.

Priest, F. G. (1984). Extracellular Enzymes. Aspects of Microbiology, vol. 9. Washington, DC: ASM.

ReichenbaCH, H. (1981). Taxonomy of the gliding bacteria. Annual Review of Microbiology 35, 339364.

ThirunavukKarasu, M. \& Priest, F. G. (1984). Purification of an extracellular and a cellular $\alpha$ glucosidase from Bacillus licheniformis. Journal of General Microbiology 130, 3135-3141. 
VON TIGERSTROM, R. G. (1980). Extracellular nucleases of Lysobacter enzymogenes: production of the enzymes and purification and characterization of an endonuclease. Canadian Journal of Microbiology 26, 1029-1037.

voN TIGERSTROM, R. G. (1981). Extracellular nucleases of Lysobacter enzymogenes: purification and characterization of a ribonuclease. Canadian Journal of Microbiology 27, 1080-1086.

voN TIgerstrom, R. G. (1983). The effect of magnesium and manganese ion concentrations and medium composition on the production of extracellular enzymes by Lysobacter enzymogenes. Journal of General Microbiology 129, 2293-2299.

von Tigerstrom, R. G. (1984). Production of two phosphatases by Lysobacter enzymogenes and purification and characterization of the extracellular enzyme. Applied and Environmental Microbiology 47, 693-698.

von Tigerstrom, R. G. \& Stelmaschux, S. (1985). Localization of the cell-associated phosphatase in Lysobacter enzymogenes. Journal of General Microbiology 131, 1611-1618.

WARBURG, O. \& Christuan, W. (1941). Isolierung und Kristallisation des Garungsferments Enolase. Biochemische Zeitschrift 310, 384-421.

WhITAKER, D. R. (1970). The $\alpha$-lytic protease of a myxobacterium. Methods in Enzymology 19, 599613. 